\title{
MANDATORY JOINT AUDIT AND AUDIT QUALITY IN THE CONTEXT OF THE EUROPEAN BLUE CHIPS
}

\author{
Josep GARCIA-BLANDON ${ }^{*}$, David CASTILLO-MERINO${ }^{1}$, \\ Josep M. ARGILÉS-BOSCH${ }^{2}$, Diego RAVENDA ${ }^{3}$ \\ ${ }^{1}$ IQS School of Management, Universitat Ramon Llull, Barcelona, Spain \\ ${ }^{2}$ Department of Accounting, Universitat de Barcelona, Barcelona, Spain \\ ${ }^{3}$ Department of Accounting, TBS Business School, Barcelona, Spain
}

Received 10 August 2020; accepted 08 February 2021

\begin{abstract}
This study investigates audit quality under joint and single audit regimes with a sample of large European firms. Both, the economic relevance of these companies, and the fact that the impact of joint audit on audit quality should be stronger when the audited company is a blue-chip firm motivate the study. If mandatory joint audit were positively associated with audit quality, French firms, under mandatory joint audit since 1966, should present higher audit quality compared to their European peers. The results do not indicate this to be the case. Specifically, similar levels of discretionary accruals are observed for French and other European firms. Furthermore, for the first time in the literature, evidence is reported indicating that French firms may even present lower audit quality than their European peers, when audit quality is measured by the likelihood of just beating earnings benchmarks. These results are expected to inform the ongoing debate in several countries about joint audits.
\end{abstract}

Keywords: mandatory joint audit, audit quality, discretionary accruals, earnings benchmarks, Standard and Poor's 350 Europe, audit firm type.

JEL Classification: M42.

\section{Introduction}

A joint audit occurs when a client is simultaneously and separately audited by two or more audit firms that sign the audit report (Deng et al., 2014). Even though, apart from France, joint audit is not currently mandatory in the EU; from 1930 to 2005, public Danish firms were also required to conduct joint audits. Nonetheless, the convenience of making joint audits mandatory periodically surfaces as a hot issue in the agenda of regulators and policymakers, and it is currently encouraged by the European regulation.

*Corresponding author. E-mail: josep.garcia@iqs.edu

Copyright (c) 2021 The Author(s). Published by Vilnius Gediminas Technical University

This is an Open Access article distributed under the terms of the Creative Commons Attribution License (http://creativecommons. org/licenses/by/4.0/), which permits unrestricted use, distribution, and reproduction in any medium, provided the original author and source are credited. 
Based on the French experience, the Green Paper on Audit Policy (European Commission [EC], 2010) proposes joint audits as a policy for improving audit quality. Nevertheless, the regulation finally approved by the European Parliament in 2014 (European Parliament [EP], 2014) incorporates the join audit issue to the final regulation only as a recommendation. More recently, in the UK, a report released by the Competition and Markets Authority (CMA) in April 2019 "recommends mandatory joint audit, to increase the capacity of challengers, to increase choice in the market and thereby drive up audit quality" (Competition and Markets Authority [CMA], 2019). The report has caused intense controversy and debate in the audit profession (Financial Times [FT], 2019¹). Similarly, South Africa has recently imposed mandatory joint audit for large banks, and is considering extending this rule to the large public companies (Institute of Chartered Accountants in England and Wales [ICAEW], 2019). The interest and practical implications of the issue are also clear from a recent report by the International Federation of Accountants [IFAC] (2020), as well as the need of further research to support a policy position (Siddiqui, 2019).

The study investigates whether audit quality is higher in France, under a mandatory joint audit rule for listed companies since 1966, than in the rest of Europe, not subject to such a rule. The empirical analysis is based on the Standard and Poor's 350 index for Europe (hereinafter S\&P350EUROPE), from 2009 to 2016. Audit quality is proxied by discretionary accruals and earnings benchmarks.

The motivation relies on the need of expanding and updating the available evidence which so far is not informative enough. First, because empirical research on mandatory joint audits is scarce, with only a few articles empirically investigating its impact on financial reporting quality. Two of them examine the situation in Denmark around the abandonment of the mandatory joint audit rule in 2004 (Lesage et al., 2017; Holm \& Thinggaard, 2018), and a third one (André et al., 2016) investigates differences in audit quality between French firms (subject to mandatory joint audit) and Italian and UK firms (not subject to joint audit). Secondly, the evidence reported by Lesage et al. (2017) and Holm and Thinggaard (2018) refers to the Danish audit market at the beginning of the century, and after the important changes which have affected the audit activity since then (i.e., Directive 2006/43/EC on statutory audits), is not informative enough for the ongoing debate. Finally, the extant evidence is mostly based on discretionary accruals. Both, the difficulties associated with the concept of audit quality as well as the limitations of discretionary accruals as an adequate proxy (DeFond \& Zhang, 2014) advocate the use of additional metrics.

This study contributes to the literature by addressing the above gaps. Whereas it follows a similar approach as André et al. (2016), there are important differences between both studies. First, it examines a more recent period, and thus, is more informative for the current debate on mandatory joint audit. Second, André et al. (2016) choose Italy and the UK as the benchmark countries for France, though the sample of companies for this study includes companies from 16 European countries. Given the relevance of the environmental setting for the issue investigated (Albersmann \& Quick, 2020; Lobo et al., 2017), the differences

\footnotetext{
1 “The CMA alarmed the UK's largest accounting firms last April when it announced proposals to reform the industry, including mandatory joint audits and an operational separation of the consulting and audit divisions of the Big Four firms" (FT, 2020).
} 
between France, Italy and the UK make it difficult to assume that any observed difference in audit quality between these countries is caused by the different joint audit regulation. To overcome this limitation, segmented analyses are conducted limited to those countries which are viewed as more comparable to France in terms of the institutional setting for the audit activity. Third, as the analysis relies on the constituents of the S\&P350EUROPE, the sample of companies is relatively homogeneous and this reduces the potential incidence of variable omission problems. More importantly, the main justification for joint audit is that two audit firms can benefit from their mutual expertise (Bédard et al., 2014). However, this potential benefit should be more relevant in the auditing of large and more complex firms. Similarly, a key argument against joint audits is that the two auditors can compete to please the client, as a strategy to sell more services (Ratzinger-Sakel et al., 2013). Thus, as in the former case, this issue should be particularly relevant when the audited client is a large (and more rewarding) firm. Therefore, blue chip companies provide the perfect research setting for the investigation of joint audits and audit quality.

The results of the study do not suggest different audit quality between joint and single audit regimes, when audit quality is proxied by discretionary accruals. This result is in line with prior studies' findings. However, firms under mandatory joint audit are more likely to restate earnings than other firms. Therefore, mandatory joint audit may even diminish audit quality.

The paper continues as follows. The next section summarizes the background and develops the hypothesis. Section 2 outlines the research design and describes the dataset. Afterwards, Sections 3 and 4 present and discuss the results. Finally, the paper ends with the conclusions section.

\section{Background and hypothesis development}

The proponents of joint audits argue that two audit firms auditing the same client will result in higher total information precision (Deng et al., 2014). Following DeAngelo's (1981) definition of audit quality as the probability that the auditor detects (competence) and reports (independence) an accounting misstatement, the probability of detecting a misstatement should be higher under a joint audit scheme, as there are two audit firms looking for potential accounting misstatements (the so-called "four eyes" argument). Moreover, Bédard et al. (2014) point out that under joint audit, both audit firms benefit from their mutual technical and geographical expertise. As for the potential impact of joint audits on the independence dimension of audit quality, Bédard et al. (2014: 12) claim that "[... joint audit would provide auditors with greater incentive to stand their ground in the case of disagreement between one auditor and the audited firm". Besides, Deng et al. (2014) notice the stronger difficulties (and higher costs) of "bribing" two auditors instead of one. This is also the view of Nurunnabi et al. (2020), who point out that accounting professionals attribute several benefits to joint audits

However, there are also arguments suggesting a negative impact of joint audits on audit quality. The so-called "free riding" problem (Deng et al., 2014) advocates that under joint audits each audit firm has incentives to save audit resources, and therefore, the outcome could be lower audit quality. Another argument stresses the operational problems, as joint 
audits require a clear delimitation of the audit tasks between audit firms (Bédard et al., 2014). Additionally, Ratzinger-Sakel et al. (2013) point out the very difficulties that the same audit firms which compete for keeping the client in the next years, cooperate closely in the audit of this same client. Similarly, Quick and Schmidt (2018) argue that joint audits may undermine auditor independence because both auditors may compete to please the client. Finally, Hoos et al. (2019) note that under joint audit, auditors may the less willing to issue going concern modified opinions.

With regard to the available evidence, Lesage et al. (2017) and Holm and Thinggaard (2018) take advantage of the unique Danish setting (where public companies had to conduct joint audits until 2005). Lesage et al. (2017) investigate the years between 2002 and 2010, not observing any association between joint audits and audit quality. Subsequently, Holm and Thinggaard (2018) address the joint audit-audit quality relationship by making use of both qualitative and archival research methods. As for the first approach, the results of a survey of Danish chief financial officers (CFO) show that they do not perceive different levels of audit quality under single or joint audit regimes. This was further supported by the empirical analysis conducted for the 2004-2008 research period. Lesage et al. (2017) and Holm and Thinggaard (2018) measure audit quality by discretionary accruals, and Lesage et al. (2017) also use the likelihood of meeting earnings benchmarks. Both studies implicitly assume that any change in audit quality between 2002 and 2010 (Lesage et al., 2017) or between 2004 and 2008 (Holm \& Thinggaard, 2018) is due to the change in the joint audit regulation; therefore, ignoring other potentially important events for the audit activity, such as the implementation of the mandatory audit partner rotation in the EU. The inclusion of year-fixed effects in the models does not allow to control for confounding effects. Second, if, as Ball et al. (2000) and Bédard (2012) point out, the institutional context becomes crucial to understand the auditorclient relationship, the evidence reported for Denmark at the beginning of the century cannot be generalized to the whole European audit sector nowadays.

André et al. (2016) compare audit quality of listed companies in France, with the situation in Italy and the UK. The study is conducted for the 2007-2011 research period and, as Lesage et al. (2017) and Holm and Thinggaard (2018), measure audit quality with accrualbased variables. They do not observe different audit quality between France and either Italy or the UK. However, if, as pointed out in the introduction of the paper, the joint audit-audit quality relationship is conditioned by the size of the audited company, both the inclusion in André et al's (2016) sample of large and small firms alike, and the fact that the weights of both types of firms in each of the countries examined are likely to be different may led to misleading results.

The above theoretical studies have developed arguments supporting both positive and negative effects of joint audit on audit quality. However, on the basis of these studies, there is not an obvious prediction about the sign of the final effect, in case this effect existed. Besides, the extant empirical evidence has failed to observe a significant impact of joint audit and audit quality. Consequently, similar to Lesage et al. (2017) and Holm and Thinggaard (2018), the hypothesis is posed in the null form:

Hypothesis: Firms under single or mandatory joint audit do not present different audit quality. 


\section{Research design and sample}

\subsection{Research design}

Following previous studies, audit quality is proxied by discretionary accruals (e.g., André et al., 2016; Garcia-Blandon et al., 2020; Holm \& Thinggaard, 2018; Lesage et al., 2017). Besides, the multinational nature of the sample suggests to use also abnormal working capital accruals (AWCA) (Francis \& Wang, 2008). Like prior studies (DeFond \& Park, 2001), AWCA are computed as the firm's actual working capital minus the necessary working capital according to its sales, lagged by total assets (Carey \& Simnett, 2006).

$$
A W C A_{t}=W C_{t}-\left[\left(W C_{t-1} / S_{t-1}\right) x S_{t}\right],
$$

where: $W C$ - non-cash working capital: (current assets - cash and near cash assets) - (current liabilities - short-term debt) and $S$ - sales.

Like André et al. (2016), absolute discretionary accruals (ABSAWCA) is the main indicator of audit quality. However, additional analyses with raw discretionary accruals $(A W C A)$ (Carey \& Simnett, 2006; Francis \& Wang, 2008), and with absolute (ABSCURACC) and raw (CURACC) current working capital accruals ${ }^{2}$ (Carey \& Simnett, 2006) are conducted.

Afterwards, for comparison reasons, the regression model is based on André et al. (2016), with discretionary accruals in absolute values being the dependent variable in Eq. (2); whereas FRANCE is the variable of interest, and the model also includes the usual controls. Estimations are conducted using the Stata 14 software.

$$
\begin{gathered}
\text { ABSAWCAi,t }=\beta_{0}+\beta_{1} \text { FRANCE }_{i}, t+\beta_{2} \text { REVENUESi, } t+\beta_{3} \text { ROA } i, t+\beta_{4} \text { FINLEVER } i, t+ \\
\beta_{5} \text { LLOSSESi,t }+\beta_{6} \text { MTBi,t }+\beta_{7} \text { REVENGROWTHi,t }+\beta_{8} \text { PPEGROWTHi,t }+ \\
\beta_{9} \text { HELDCLOSELY } i, t+\beta_{10} \text { USLISTED } i, t+\text { fixed effects } s_{i, t}+\rho_{i, t} .
\end{gathered}
$$

Dependent variable:

$A B S A W C A$ in the main analysis. AWCA, ABSCURACC and CURACC are used in additional analyses.

Variable of interest:

FRANCE equals 1 for French companies, and 0 otherwise.

Control variables:

REVENUES is the logarithm of total revenue;

$R O A$ is return on assets;

FINLEVER is total liabilities divided by total assets;

LLOSSES equals 1 for companies reporting losses the previous year, and 0 otherwise;

$M T B$ is the market-to-book ratio;

REVENGROWTH is the annual growth of revenues;

PPEGROWTH is the annual growth of property, plant and equipment;

\footnotetext{
${ }^{2}$ Current working capital is the increase in non-cash current assets less increase in current liabilities (minus change in short-term debt).
} 
HELDCLOSELY is the percentage of shares closely held;

USLISTED equals 1 for companies cross-listed in the US, and 0 otherwise; and $\rho$ is the error term.

Year and industry fixed effects are also included in Eq. (2).

A negative coefficient is anticipated for REVENUES, as larger firms are expected to show higher financial reporting quality, and therefore, lower accruals. ROA, FINLEVER and LLOSSES are indicators of financial health. As firms in better financial health should have less discretionary accruals, a negative (positive) coefficient for ROA (FINLEVER and LLOSSES) is anticipated. A positive coefficient is also predicted for $M T B$, because firms quoted at higher multiples have stronger incentives for earnings management. Cross-listed firms are expected to show higher financial reporting quality, as they are subject to stronger scrutiny; thus, a negative coefficient is expected for USLISTED. Finally, as André et al. (2016), no prediction on the sign of HELDCLOSELY, REVENGROWTH and PPEGROWTH is made.

\subsection{Sample}

The sample consists of the constituents of the S\&P350EUROPE index by September 15, 2017. The research period is from 2009 to 2016 and Capital IQ is the source of data for constructing the variables. Given the 350 constituents of the index and the eight-year research period, the initial size of the sample is 2,800 firm-year observations. Nevertheless, as prior studies, financial companies (504 observations) are removed. Furthermore, 283 observations are dropped for lack of information, leading to a final sample of 2013 observations. The country composition of the final sample is as follows: the UK (27\%), France (14\%), Germany (13\%), Switzerland (7\%), Sweden (7\%), Netherlands (6\%), Spain (5\%), Denmark (4\%), Italy (4\%), Finland (3\%), Belgium (2\%), Ireland (2\%), Luxemburg (2\%), Norway (2\%), Austria (1\%) and Portugal (1\%).

Table 1. Descriptive statistics

\begin{tabular}{|c|c|c|c|c|c|}
\hline \multicolumn{6}{|l|}{ Panel A: France } \\
\hline & mean & p50 & sd & p25 & p75 \\
\hline$A B S A W C A$ & .0200101 & .0101723 & .0328283 & .004746 & .020672 \\
\hline REVENUES & 9.59673 & 9.686101 & 1.187713 & 8.932477 & 10.43841 \\
\hline$R O A$ & .0457727 & .0402835 & .0307532 & .027718 & .055828 \\
\hline FINLEVER & .642054 & .649671 & .1540469 & .5545209 & .7545175 \\
\hline LLOSSES & .0744681 & 0 & .2629978 & 0 & 0 \\
\hline MTB & 1.788755 & 1.510186 & 1.729303 & .9908006 & 2.368921 \\
\hline REVENGROWTH & .0343544 & .036679 & .1168069 & -.020753 & .08944 \\
\hline PPEGROWTH & .0481207 & .0482869 & .1559964 & .0140629 & .0918824 \\
\hline HELDCLOSELY & .2600938 & .2357045 & .2199605 & .058184 & .4121089 \\
\hline USLISTED & .2726366 & .2452575 & .2251973 & .0581840 & .4175186 \\
\hline Observations & 282 & & & & \\
\hline
\end{tabular}


End of Table 1

\begin{tabular}{|l|c|c|c|c|c|}
\hline \multicolumn{5}{|c|}{ Panel B: Other European countries } \\
\hline & mean & $\mathrm{p} 50$ & $\mathrm{sd}$ & $\mathrm{p} 25$ & $\mathrm{p} 75$ \\
\hline ABSAWCA & .0261061 & .0150246 & .0377217 & .0064263 & .030173 \\
\hline REVENUES & 9.018368 & 9.038721 & 1.277682 & 8.112138 & 9.856904 \\
\hline ROA & .0629396 & .0554 & .0416319 & .035436 & .07983 \\
\hline FINLEVER & .6164155 & .6207927 & .1663258 & .5078003 & .7310541 \\
\hline LLOSSES & .0908039 & 0 & .2874132 & 0 & 0 \\
\hline MTB & 4.015842 & 2.270618 & 59.47653 & 1.241718 & 3.746209 \\
\hline REVENGROWTH & .0507974 & .040838 & .1567647 & -.019895 & .110412 \\
\hline PPEGROWTH & .0438447 & .0513774 & .1987137 & .0039041 & .1032434 \\
\hline HELDCLOSELY & .1827253 & .1160637 & .1938897 & .0176279 & .303395 \\
\hline USLISTED & .2010350 & .1199264 & .2274507 & .0187310 & .316133 \\
\hline Observations & 1731 & & & & \\
\hline
\end{tabular}

Table 1 shows the descriptive statistics for the variables in Eq. (3), differentiating between French firms (Panel A of Table 1) and firms from other European countries (Panel B of Table 1). The most interesting result is that French firms present lower discretionary accruals $(A B S A W C A)$, thus suggesting higher audit quality. The correlation matrix (untabulated) reveals rather moderate Pearson correlation coefficients between the independent variables; the largest coefficient in absolute values being -0.24, between ROA and FINLEVER. Accordingly, multicollinearity does not seem to be a problem.

\section{Results of the study}

In the first estimation of the model, the dependent variable is $A B S A W C A$. To minimize the effects of outliers, variables are winsorized at the $1 \%$ and $99 \%$ levels. Besides, because of the panel structure of the dataset, panel data estimations are conducted. The nature of the variable of interest FRANCE, showing no variation for any firm in the sample across the research period, discards the use of fixed effects models in the estimations. Therefore, Eq. (3) is estimated with random effects. Moreover, to avoid heteroscedasticity problems, significance tests are conducted with robust standard errors.

The estimates of Eq. (2) are shown in Table 2 (Columns (1) to (4)). All four estimations are globally significant ( $p$-value $<0.01)$. As in Carey and Simnett (2006), R-squared are higher in the models with accruals in absolute values (ABSAWCA and ABSCURACC) than in the models using raw accruals ( $A W C A$ and CURACC). Interestingly, FRANCE is insignificant in all the estimations. Therefore, French firms, under mandatory joint audit, do not present significantly different accruals than the remaining firms, and this result holds no matter how accruals are computed. This result is consistent with André et al. (2016) and supports the hypothesis of the study. 
Table 2. The relationship between joint audit and discretionary accruals. Estimations with the whole sample (Columns (1) to (4)), and with a matched sample (Column (5))

\begin{tabular}{|c|c|c|c|c|c|}
\hline \multirow[b]{2}{*}{ VARIABLES } & (1) & (2) & (3) & (4) & (5) \\
\hline & ABSAWCA & AWCA & ABSCURACC & CURACC & $\begin{array}{c}\text { ABSAWCA } \\
\text { with a } \\
\text { matched } \\
\text { sample }\end{array}$ \\
\hline \multirow{2}{*}{ FRANCE } & -0.00466 & 0.00328 & -0.00320 & 0.00215 & -0.00541 \\
\hline & $(0.00308)$ & $(0.00254)$ & $(0.00246)$ & $(0.00244)$ & $(0.00430)$ \\
\hline \multirow{2}{*}{ REVENUES } & $-0.00800^{\star * \star}$ & -0.000335 & $-0.00520^{\star * \star}$ & -0.000582 & $-0.01169^{* \star \star}$ \\
\hline & $(0.00192)$ & $(0.000835)$ & $(0.00120)$ & $(0.000773)$ & $(0.00436)$ \\
\hline \multirow{2}{*}{$R O A$} & -0.0715 & 0.0181 & 0.00203 & -0.00739 & $-0.19157^{\star *}$ \\
\hline & $(0.0505)$ & $(0.0316)$ & $(0.0329)$ & $(0.0304)$ & $(0.08711)$ \\
\hline \multirow{2}{*}{ FINLEVER } & 0.0152 & -0.00288 & 0.00724 & $-0.0151^{\star *}$ & 0.03678 \\
\hline & $(0.00957)$ & $(0.00668)$ & $(0.00724)$ & $(0.00698)$ & $(0.03201)$ \\
\hline \multirow{2}{*}{ LLOSSES } & $0.00757^{\star}$ & -0.00479 & $0.00847^{\star * \star}$ & $-0.00722^{\star * \star}$ & -0.00615 \\
\hline & $(0.00405)$ & $(0.00337)$ & $(0.00303)$ & $(0.00273)$ & $(0.00842)$ \\
\hline \multirow[t]{2}{*}{$M T B$} & $\begin{array}{c}-2.44 \mathrm{e}- \\
05^{\star * \star}\end{array}$ & $1.34 \mathrm{e}-05$ & $-8.74 \mathrm{e}-06^{\star * \star}$ & $3.56 \mathrm{e}-05^{\star * *}$ & 0.00180 \\
\hline & $(2.87 \mathrm{e}-06)$ & $(1.30 \mathrm{e}-05)$ & $(2.33 \mathrm{e}-06)$ & $(8.97 e-06)$ & $(0.00117)$ \\
\hline \multirow{2}{*}{ REVENGROWTH } & -0.00587 & -0.00246 & -0.00534 & -0.00640 & -0.03775 \\
\hline & $(0.00980)$ & $(0.0130)$ & $(0.00676)$ & $(0.0103)$ & $(0.02554)$ \\
\hline \multirow{2}{*}{ PPEGROWTH } & $-0.0159^{* * *}$ & 0.00455 & $-0.0138^{\star \star \star}$ & 0.00798 & -0.01945 \\
\hline & $(0.00588)$ & $(0.00711)$ & $(0.00436)$ & $(0.00666)$ & $(0.01530)$ \\
\hline \multirow{2}{*}{ HELDCLOSELY } & -0.00126 & -0.00380 & -0.00270 & $-0.00560^{*}$ & -0.00597 \\
\hline & $(0.00767)$ & $(0.00314)$ & $(0.00529)$ & $(0.00311)$ & $(0.01095)$ \\
\hline \multirow{2}{*}{ UNLISTED } & 0.000724 & -0.00364 & -0.000337 & -0.00286 & -0.00263 \\
\hline & $(0.00417)$ & $(0.00223)$ & $(0.00341)$ & $(0.00270)$ & $(0.00921)$ \\
\hline \multirow{2}{*}{ Constant } & $0.107^{\star \star \star}$ & -0.00873 & $0.0805^{\star \star \star}$ & -0.00284 & $0.13513^{* \star *}$ \\
\hline & $(0.0212)$ & $(0.0112)$ & $(0.0143)$ & $(0.00957)$ & $(0.04179)$ \\
\hline Observations & 2,013 & 2,013 & 2,013 & 2,013 & 565 \\
\hline Industry FE & YES & YES & YES & YES & YES \\
\hline $\begin{array}{l}\text { Year FE } \\
\text { R-sq. } \\
\text { Wald chi2 }\end{array}$ & $\begin{array}{c}\text { YES } \\
0.0724 \\
115.97^{\star * *}\end{array}$ & $\begin{array}{c}\text { YES } \\
0.0175 \\
54.08^{* * *}\end{array}$ & $\begin{array}{c}\text { YES } \\
0.0684 \\
85.25^{\star * *}\end{array}$ & $\begin{array}{c}\text { YES } \\
0.0496 \\
125.76^{* * *}\end{array}$ & $\begin{array}{c}\text { YES } \\
0.0995 \\
39.60^{* *}\end{array}$ \\
\hline
\end{tabular}

Note: ${ }^{* *} \mathrm{p}<0.01,{ }^{* *} \mathrm{p}<0.05,{ }^{*} \mathrm{p}<0.1$.

Afterwards, several checks intend to assess the robustness of the above results. The first one assesses the potential impact of endogeneity on the results. This could be the case, for example, if French companies were not comparable to their European peers, due to some specific features. In such a situation, differences in audit quality between French and other European firms could be explained by these differences; therefore, having nothing to do 
with the joint audit regulation. To address this issue, the propensity score method is used to obtain a matched sample with homogenous characteristics. Hence, a logistic regression with FRANCE being the dependent variable and the control variables included in Eq. (2) is conducted to obtain the matched sample, and afterwards this sample is used to re-estimate Eq. (2) with $A B S A W C A$ as the dependent variable. The new results, in Column (5), show a negative and insignificant coefficient for FRANCE, exactly the same as in the main estimation with the full sample (see Column (1)). Therefore, endogeneity does not seem to have affected the results.

The following analysis controls for the fact that a few firms in the sample have conducted voluntary joint audits. Since the aim of this paper is to study whether firms under mandatory joint audit present significantly different levels of audit quality, these firms were included in sample for the main analysis. However, now Eq. (2) is re-estimated after removing these firms from the sample. Given the low incidence of voluntary audits in the sample (20 firmyear observations), it is not surprising that the new results (untabulated) similar as those in Table 2. Similarly, Eq. (2) is also re-estimated after removing from the sample 110 firm-year observations affected by audit firm changes, as these changes may be associated with abnormal levels of discretionary accruals without necessarily indicating poor audit quality. The new results (untabulated) are consistent with Table 2, discarding any significant relationship between joint audit and audit quality.

Subsequently, with the aim of diminishing the potential influence of the differences in the institutional settings between France and other European countries, new estimations are conducted with segmented samples. First, firms proceeding from the Anglo-Saxon area (the UK and Ireland in the sample) are removed, as this is the most dissimilar setting to France in terms of auditor litigation risk. The estimates of Eq. (2) with the new subsample are shown in Table 3. In the estimations conducted with accruals in absolute value (Columns (1) and (3)), FRANCE has a negative and significant coefficient ( $p$-value $<0.05$ for $A B S A W C A$, and $p$-value $<0.10$ for $A B S C U R A C C)$. However, in none of the remaining estimations (Columns (2) and (4)) FRANCE presents a significant coefficient. Next, the sample is reduced to only those firms proceeding from countries with a French civil-law origin, based on La Porta et al.s (1998) classification scheme (Belgium, Luxemburg, Italy, Netherlands, Portugal and Spain). The new results, in Table 4, show insignificant coefficients for FRANCE in all the new estimations, and the same holds when Italian firms are also excluded from the sample (results untabulated), given the different regulation regarding audit firm rotation between Italy and France during the research period. Therefore, when the analysis is limited to those countries which are considered as the most similar to France in terms of the institutional setting, differences in accruals between French firms and other firms are insignificant. Accordingly, mandatory joint audits do not seem to involve different audit quality.

The next analysis addresses whether the type of audit firms in the joint audit is of any relevance for the issue investigated. This may be important, as a main reason behind the positive view of EU regulators towards joint audits is to favour smaller audit firms (EP, 2014) ${ }^{3}$.

\footnotetext{
${ }^{3}$ According to Kermiche and Piot (2018), the joint-audit regulation has succeeded in mitigating the market concentration.
} 
Table 3. The relationship between joint audits and discretionary accruals. Results of the estimations conducted with the non-Anglo-Saxon subsample

\begin{tabular}{|c|c|c|c|c|}
\hline \multirow{2}{*}{ VARIABLES } & (1) & (2) & (3) & (4) \\
\hline & ABSAWCA & AWCA & ABSCURACC & CURACC \\
\hline \multirow{2}{*}{ FRANCE } & $-0.00762^{\star \star}$ & 0.00306 & $-0.00495^{\star}$ & 0.00189 \\
\hline & $(0.00343)$ & $(0.00252)$ & $(0.00256)$ & $(0.00253)$ \\
\hline \multirow{2}{*}{ REVENUES } & $-0.0100^{\star * *}$ & -0.000169 & $-0.00633^{* * *}$ & -0.000673 \\
\hline & $(0.00241)$ & $(0.00101)$ & $(0.00152)$ & $(0.000924)$ \\
\hline \multirow{2}{*}{$R O A$} & $-0.129^{\star}$ & -0.0478 & -0.0396 & -0.0418 \\
\hline & $(0.0689)$ & $(0.0429)$ & $(0.0434)$ & $(0.0376)$ \\
\hline \multirow{2}{*}{ FINLEVER } & 0.0176 & -0.0126 & 0.00815 & $-0.0193^{\star \star}$ \\
\hline & $(0.0129)$ & $(0.00890)$ & $(0.00984)$ & $(0.00981)$ \\
\hline \multirow{2}{*}{ LLOSSES } & $0.0115^{\star *}$ & $-0.0109^{\star * *}$ & $0.0116^{* * *}$ & $-0.00931^{* * *}$ \\
\hline & $(0.00522)$ & $(0.00381)$ & $(0.00389)$ & $(0.00330)$ \\
\hline \multirow{2}{*}{ MTB } & $-4.45 e-05$ & $0.000219^{\star *}$ & $-5.64 \mathrm{e}-05^{\star *}$ & $0.000188^{* * *}$ \\
\hline & $(2.78 \mathrm{e}-05)$ & $(8.74 \mathrm{e}-05)$ & $(2.41 \mathrm{e}-05)$ & $(6.31 \mathrm{e}-05)$ \\
\hline \multirow{2}{*}{ REVENGROWTH } & -0.00440 & -0.00529 & -0.00502 & -0.0127 \\
\hline & $(0.0133)$ & $(0.0176)$ & $(0.00923)$ & $(0.0134)$ \\
\hline \multirow{2}{*}{ PPEGROWTH } & $-0.0171^{\star *}$ & 0.0101 & $-0.0162^{\star * *}$ & 0.0116 \\
\hline & $(0.00698)$ & $(0.00881)$ & $(0.00526)$ & $(0.00840)$ \\
\hline \multirow{2}{*}{ HELDCLOSELY } & -0.00876 & -0.00252 & -0.00725 & -0.00390 \\
\hline & $(0.00878)$ & $(0.00363)$ & $(0.00631)$ & $(0.00370)$ \\
\hline \multirow{2}{*}{ USLISTED } & 0.00451 & -0.00512 & 0.00437 & -0.00176 \\
\hline & $(0.00656)$ & $(0.00368)$ & $(0.00537)$ & $(0.00465)$ \\
\hline \multirow{2}{*}{ Constant } & $0.134^{\star * *}$ & 0.00101 & $0.0963^{\star * *}$ & 0.00454 \\
\hline & $(0.0290)$ & $(0.0143)$ & $(0.0193)$ & $(0.0129)$ \\
\hline Observations & 1,476 & 1,476 & 1,476 & 1,476 \\
\hline Industry FE & YES & YES & YES & YES \\
\hline $\begin{array}{l}\text { Year FE } \\
\text { R-sq. } \\
\text { Wald chi2 }\end{array}$ & $\begin{array}{c}\text { YES } \\
0.1003 \\
69.50^{* * *}\end{array}$ & $\begin{array}{c}\text { YES } \\
0.0275 \\
58.10^{* * *}\end{array}$ & $\begin{array}{c}\text { YES } \\
0.0864 \\
77.52^{\star * \star}\end{array}$ & $\begin{array}{c}\text { YES } \\
0.0561 \\
93.58^{\star * \star}\end{array}$ \\
\hline
\end{tabular}

Note: ${ }^{* * *} \mathrm{p}<0.01,{ }^{* *} \mathrm{p}<0.05,{ }^{*} \mathrm{p}<0.1$.

Table 4. The relationship between joint audits and discretionary accruals. Results of the estimations conducted with the French-civil-law subsample

\begin{tabular}{|l|c|c|c|c|}
\hline \multirow{2}{*}{ VARIABLES } & $(1)$ & $(2)$ & $(3)$ & $(4)$ \\
\cline { 2 - 5 } & ABSAWCA & AWCA & ABSCURACC & CURACC \\
\hline \multirow{2}{*}{ FRANCE } & -0.00383 & 0.00360 & -0.00203 & 0.00478 \\
\cline { 2 - 5 } & $(0.00486)$ & $(0.00331)$ & $(0.00361)$ & $(0.00327)$ \\
\hline \multirow{2}{*}{ REVENUES } & $-0.00810^{* * *}$ & 0.00171 & $-0.00462^{* *}$ & 0.000191 \\
\cline { 2 - 5 } & $(0.00312)$ & $(0.00190)$ & $(0.00191)$ & $(0.00171)$ \\
\hline
\end{tabular}


End of Table 4

\begin{tabular}{|c|c|c|c|c|}
\hline \multirow{2}{*}{ VARIABLES } & (1) & (2) & (3) & (4) \\
\hline & ABSAWCA & AWCA & ABSCURACC & CURACC \\
\hline \multirow{2}{*}{$R O A$} & -0.123 & 0.0990 & -0.0503 & $0.121^{\star *}$ \\
\hline & $(0.0928)$ & $(0.0606)$ & $(0.0657)$ & $(0.0559)$ \\
\hline \multirow{2}{*}{ FINLEVER } & 0.0379 & 0.0123 & 0.0247 & 0.0115 \\
\hline & $(0.0238)$ & $(0.0133)$ & $(0.0156)$ & $(0.0132)$ \\
\hline \multirow{2}{*}{ LLOSSES } & $0.0137^{\star}$ & -0.00665 & $0.00927^{\star}$ & -0.00212 \\
\hline & $(0.00709)$ & $(0.00614)$ & $(0.00493)$ & $(0.00439)$ \\
\hline \multirow{2}{*}{ MTB } & $-6.44 \mathrm{e}-05^{\star}$ & $0.000286^{* * *}$ & $-8.21 \mathrm{e}-05^{\star * *}$ & $0.000251^{* * *}$ \\
\hline & $(3.63 e-05)$ & $(2.27 \mathrm{e}-05)$ & $(2.29 \mathrm{e}-05)$ & $(2.31 \mathrm{e}-05)$ \\
\hline \multirow{2}{*}{ REVENGROWTH } & -0.00149 & -0.0199 & -0.0106 & $-0.0241^{\star}$ \\
\hline & $(0.0211)$ & $(0.0195)$ & $(0.0143)$ & $(0.0140)$ \\
\hline \multirow{2}{*}{ PPEGROWTH } & $-0.0240^{\star *}$ & 0.00941 & $-0.0166^{*}$ & 0.00875 \\
\hline & $(0.0118)$ & $(0.0126)$ & $(0.00876)$ & $(0.0108)$ \\
\hline \multirow{2}{*}{ HELDCLOSELY } & -0.00487 & $0.00870^{*}$ & -0.00329 & $0.00940^{\star *}$ \\
\hline & $(0.0109)$ & $(0.00524)$ & $(0.00822)$ & $(0.00457)$ \\
\hline \multirow{2}{*}{ USLISTED } & 0.0135 & -0.00371 & 0.0114 & 0.00134 \\
\hline & $(0.0116)$ & $(0.00659)$ & $(0.00802)$ & $(0.00780)$ \\
\hline \multirow{2}{*}{ Constant } & $0.0955^{\star \star}$ & $-0.0400^{\star}$ & $0.0641^{\star \star}$ & $-0.0350^{\star}$ \\
\hline & $(0.0405)$ & $(0.0238)$ & $(0.0271)$ & $(0.0195)$ \\
\hline Observations & 661 & 661 & 661 & 661 \\
\hline Industry FE & YES & YES & YES & YES \\
\hline $\begin{array}{l}\text { Year FE } \\
\text { R-sq. } \\
\text { Wald chi2 }\end{array}$ & $\begin{array}{c}\text { YES } \\
0.0892 \\
194.16^{* * *}\end{array}$ & $\begin{array}{c}\text { YES } \\
0.0422 \\
2134.59^{* * *}\end{array}$ & $\begin{array}{c}\text { YES } \\
0.0892 \\
444.63^{* * *}\end{array}$ & $\begin{array}{c}\text { YES } \\
0.0690 \\
930.95^{\star * *}\end{array}$ \\
\hline
\end{tabular}

Note: ${ }^{* *} \mathrm{p}<0.01,{ }^{* *} \mathrm{p}<0.05,{ }^{*} \mathrm{p}<0.1$.

Additionally, according to Deng et al. (2014), when both audit firms are similar in terms of technical efficiency, the joint audit will eventually result in similar audit quality as the single audit; yet when a Big 4 and a non-Big 4 auditor participate in the joint audit it will diminish audit quality. For the French market, Francis et al. (2009) observe that joint audits conducted by two Big4 firms lead to significantly lower income-increasing accruals; yet when just one Big 4 firm is appointed, the association becomes marginally significant. Lobo et al. (2017) concludes differently, observing lower audit quality under two Big4 audit firms, than under the Big4- non-Big4 combination. On the other hand, André et al. (2016) do not find any effects of auditor-pair choices on the absolute value of discretionary accruals. Eq. (3) reproduces Eq. (2) but includes 1BIG4FRANCE (1 for French companies with one Big4 firm, and 0 otherwise) and 2BIG4FRANCE (1 for French companies with two Big4 audit firms, and 0 otherwise), as the new variables of interest in substitution of FRANCE. In the sample, $48 \%$ of the French firms have one Big4 auditor and the remaining 52\% have two Big4 auditors. 
ABSAWCAi, $t=\beta_{0}+\beta_{1}$ 1BIG4FRANCEi, $t+\beta_{2} 2$ BIG4FRANCEi, $t+\beta_{3}$ REVENUESi, $t+$ $\beta_{4}$ ROAi, $t+\beta_{5}$ FINLEVER $i, t+\beta_{6}$ LLOSSESi, $t+\beta_{7}$ MTBi, $t+\beta_{8}$ REVENGROWTHi, + $\beta_{9}$ PPEGROWTHi, $t+\beta_{10}$ HELDCLOSELYi, $t+\beta_{11}$ USLISTED $i, t+$ fixed effects $i, t+\gamma_{i, t}$. (3)

Table 5 shows the new estimates. For simplicity reasons, only the estimates of the main model with $A B S A W C A$ as the dependent variable are tabulated. Column (1) presents the results for the whole sample, and Columns (2) and (3) the evidence for the non-Anglo-

Table 5 . The relationship between joint audits and discretionary accruals by audit firm type. Dependent variable: $A B S A W C A$

\begin{tabular}{|c|c|c|c|}
\hline \multirow[b]{2}{*}{ VARIABLES } & (1) & (2) & (3) \\
\hline & Whole sample & $\begin{array}{l}\text { Non-Anglo-Saxon } \\
\text { subsample }\end{array}$ & $\begin{array}{l}\text { French civil-law } \\
\text { subsample }\end{array}$ \\
\hline \multirow{2}{*}{ 1BIG4FRANCE } & -0.00593 & $-0.00894^{* *}$ & -0.00687 \\
\hline & $(0.00402)$ & $(0.00437)$ & $(0.00592)$ \\
\hline \multirow{2}{*}{ 2BIG4FRANCE } & -0.00191 & -0.00410 & -0.00273 \\
\hline & $(0.00406)$ & $(0.00414)$ & $(0.00553)$ \\
\hline \multirow{2}{*}{ REVENUES } & $-0.00809^{\star * *}$ & $-0.0101^{\star * *}$ & $-0.00870^{\star * *}$ \\
\hline & $(0.00194)$ & $(0.00244)$ & $(0.00329)$ \\
\hline \multirow{2}{*}{$R O A$} & -0.0720 & $-0.127^{\star}$ & -0.129 \\
\hline & $(0.0504)$ & $(0.0689)$ & $(0.0930)$ \\
\hline \multirow{2}{*}{ FINLEVER } & 0.0152 & 0.0181 & 0.0364 \\
\hline & $(0.00958)$ & $(0.0128)$ & $(0.0238)$ \\
\hline \multirow{2}{*}{ LLOSSES } & $0.00756^{\star}$ & $0.0116^{\star \star}$ & $0.0142^{\star}$ \\
\hline & (0.00409) & $(0.00531)$ & $(0.00726)$ \\
\hline \multirow{2}{*}{$M T B$} & $-2.45 e-05^{\star * \star}$ & $-4.46 e-05$ & $-4.95 e-05$ \\
\hline & $(2.83 e-06)$ & $(2.79 \mathrm{e}-05)$ & $(3.54 \mathrm{e}-05)$ \\
\hline \multirow{2}{*}{ REVENGROWTH } & -0.00562 & -0.00419 & -0.00104 \\
\hline & $(0.00979)$ & $(0.0133)$ & $(0.0206)$ \\
\hline \multirow{2}{*}{ PPEGROWTH } & $-0.0161^{* * *}$ & $-0.0172^{\star *}$ & $-0.0251^{\star *}$ \\
\hline & $(0.00587)$ & $(0.00696)$ & $(0.0117)$ \\
\hline \multirow{2}{*}{ HELDCLOSELY } & -0.00208 & -0.00877 & -0.00852 \\
\hline & $(0.00770)$ & $(0.00878)$ & $(0.0114)$ \\
\hline \multirow{2}{*}{ USLISTED } & 0.000666 & 0.00459 & 0.0130 \\
\hline & $(0.00418)$ & $(0.00655)$ & $(0.0117)$ \\
\hline \multirow{2}{*}{ Constant } & $0.108^{\star * *}$ & $0.134^{* * *}$ & $0.106^{* *}$ \\
\hline & $(0.0212)$ & $(0.0291)$ & $(0.0418)$ \\
\hline Observations & 2,013 & 1,476 & 661 \\
\hline Industry FE & YES & YES & YES \\
\hline $\begin{array}{l}\text { Year FE } \\
\text { R-sq. } \\
\text { Wald chi2 }\end{array}$ & $\begin{array}{c}\text { YES } \\
0.0720 \\
118.06^{\star * *}\end{array}$ & $\begin{array}{c}\text { YES } \\
0.1001 \\
69.98^{\star * *}\end{array}$ & $\begin{array}{c}\text { YES } \\
0.0874 \\
200.68^{\star * *}\end{array}$ \\
\hline
\end{tabular}

Note: ${ }^{* *} \mathrm{p}<0.01,{ }^{* \star} \mathrm{p}<0.05,{ }^{\star} \mathrm{p}<0.1$. 
Saxon and French civil-law subsamples, respectively. If, as some studies suggest (Deng et al., 2014; Francis et al., 2009), audit quality is expected to be higher when both auditors are Big 4 auditors, a significant coefficient with negative sign would be anticipated for $2 B I G$ 4FRANCE, but not necessarily for 1BIG4FRANCE. Table 5 does not support this view as 2BIG4FRANCE presents insignificant coefficients in all three estimations, and the same holds for $1 B I G 4 F R A N C E$ in the estimations with the whole sample and with the French civil-law subsample; however, the coefficient becomes significant with a negative sign $(p$-value $<0.05)$ in the estimations with the non-Anglo-Saxon subsample. This supports the result in Table 2 that French firms present significantly lower discretionary accruals compared to their nonAnglo-Saxon peers. However, as it was also the case with Table 2, this result does not hold either for the whole sample or for the French civil-law subsample.

\section{Additional analysis: Using earning benchmarks as the measure of audit quality}

Together with accruals, the ability of the firm to just meet earning benchmarks provides a usual indicator of (lack of) audit quality (e.g., Aobdia, 2019; Carey \& Simnett, 2006; CastilloMerino et al., 2020; Menon \& Williams, 2004). The use of this proxy relies on the observation that an abnormally high number of firms present small increases in the annual net income regarding the prior year (Carey \& Simnet, 2006). As managers have incentives to not deceive investors, who generally expect an increase in the current net income, the reporting of small increases in profits is interpreted in terms of poor. The use of earnings benchmarks seems particularly suitable in this study, given that the sample consists of the largest European firms, firms that concentrate the attention of investors and financial analysts.

The analysis relies on the logistic model represented by Eq. (4), based on Menon and Williams (2004).

$$
\begin{aligned}
& \operatorname{Pr}(\text { BEATS_LYR }=1)_{i, t}=\beta_{0}+\beta_{1} \text { FRANCE }_{i, t}+\beta_{2} \text { ASSETS }_{i, t}+\beta_{3} \text { MKTVAL }_{i, t}+ \\
& \beta_{4} A G E_{i, t}+\beta_{5} Z-S C O R E_{i, t}+\text { fixed effects }_{i, t}+\mu_{i, t} \text {, }
\end{aligned}
$$

where:

Dependent variable:

$B E A T S \_L Y R$ (beat last year's net income): an indicator variable which equals 1 if the increase of profits (decrease in losses) is $2 \%$ or lower over last year, and 0 otherwise.

Variable of interest:

The variable of interest (FRANCE): the same as in the former analysis with accruals.

Control variables:

ASSETS (size): total assets in logs;

MKTVAL (market value): market capitalization in logs;

$A G E$ (age): the age of the firm in logs;

Z-SCORE (probability of bankruptcy): the score of Altman's Z indicator, where higher scores indicate lower probability of bankruptcy; and

$\mu$ is the error term.

As in Eq. (2), year and industry fixed effects are included as controls. 
Table 6. Joint audits and the likelihood of just beating earnings benchmarks

\begin{tabular}{|l|c|c|c|}
\hline \multirow{4}{*}{ VARIABLES } & $(1)$ & $(2)$ & $(3)$ \\
\cline { 2 - 4 } & Whole sample & $\begin{array}{c}\text { Non-Anglo-Saxon } \\
\text { subsample }\end{array}$ & $\begin{array}{c}\text { French civil-law } \\
\text { subsample }\end{array}$ \\
\hline \multirow{2}{*}{ FRANCE } & $0.868^{* * *}$ & $0.831^{* * *}$ & $0.750^{* * *}$ \\
\cline { 2 - 4 } & $(0.212)$ & $(0.226)$ & $(0.257)$ \\
\hline \multirow{2}{*}{ ASSETS } & $-1.486^{* * *}$ & $-1.722^{* * *}$ & $-1.595^{* * *}$ \\
\hline \multirow{2}{*}{ MKTVAL } & $(0.301)$ & $(0.367)$ & $(0.588)$ \\
\hline \multirow{2}{*}{ AGE } & $1.908^{* * *}$ & $2.242^{* * *}$ & $2.342^{* * *}$ \\
\cline { 2 - 4 } & $(0.312)$ & $(0.397)$ & $(0.614)$ \\
\hline \multirow{2}{*}{ Z-Score } & -0.0634 & -0.208 & -0.521 \\
\hline \multirow{2}{*}{ Constant } & $(0.239)$ & $(0.283)$ & $-0.140^{* *}$ \\
\hline Observations & $-0.155^{* * *}$ & $-0.186^{* * *}$ & $(0.0650)$ \\
\hline Industry FE & $(0.0362)$ & $(0.0407)$ & -2.153 \\
\hline Year FE & $-1.795^{* *}$ & $-1.743^{*}$ & $(1.549)$ \\
\hline Pseudo R-sq. & $(0.806)$ & $(0.955)$ & 598 \\
Wald chi2 & 2,010 & 1,461 & YES \\
\hline
\end{tabular}

Note: ${ }^{* * *} \mathrm{p}<0.01,{ }^{* *} \mathrm{p}<0.05,{ }^{*} \mathrm{p}<0.1$.

The estimates of the multivariate logistic model with variables winsorized at the $1 \%$ and 99\% levels are shown in Table 6. Panel data models with random effects are used in the estimations. Significance test are conducted with robust standard errors. Column (1) shows the estimates of Eq. (4) with the whole sample of firms; whereas Columns (2) and (3) present the results for the non-Anglo-Saxon and French common-law subsamples, respectively. All three estimations are significant at the usual statistical levels ( $p$-value $<0.01)$. The most interesting result is the positive and significant coefficient for FRANCE in all three estimations ( $p$-value $<0.01)$, indicating that reporting a slight increase in the current net income is more likely for French firms than for their European peers. As French firms seem to be more active in earnings management, the joint audit does not seem to result in higher audit quality, but rather the contrary. As a proof of robustness, this conclusion holds in all three estimations, thus, independently of the set of comparison countries used as benchmarks for France. Whereas this finding contradicts Lesage et al. (2017), who do not observe any relationship between joint audit and the likelihood of meeting earnings benchmarks, both studies agree that mandatory joint audit does not improve the quality of audits.

Next, the same robustness checks applied in the former section are conducted. First, the observations corresponding to firms under voluntary joint audit are removed from the sample. The estimates of Eq. (4) with the new sample (untabulated) are qualitative the same as those in Table 6 . Subsequently, the observations affected by audit firm changes are excluded. 
As in the former case, results (untabulated) are similar as those in Table 6. For the next check, the $2 \%$ threshold to define a small increase in net income, is changed alternatively by $3 \%$ and $1 \%$, and subsequently Eq. (4) is re-estimated with the new earnings benchmarks. The new estimates (untabulated) are consistent with the figures in Table 6, particularly regarding FRANCE, whose coefficient is negative and significant ( $p$-value $<0.01$ in all six estimations).

Table 7. Joint audits and the likelihood of just beating earnings benchmarks by audit firm type

\begin{tabular}{|c|c|c|c|}
\hline \multirow[b]{2}{*}{ VARIABLES } & (1) & (2) & (3) \\
\hline & Whole sample & $\begin{array}{l}\text { Non-Anglo-Saxon } \\
\text { subsample }\end{array}$ & $\begin{array}{c}\text { French civil-law } \\
\text { subsample }\end{array}$ \\
\hline \multirow{2}{*}{ 1BIG4FRANCE } & $1.046^{* * *}$ & $1.034^{* * *}$ & $0.964^{* * *}$ \\
\hline & $(0.289)$ & $(0.302)$ & $(0.355)$ \\
\hline \multirow{2}{*}{ 2BIG4FRANCE } & $0.715^{\star \star \star}$ & $0.658^{\star *}$ & $0.554^{\star *}$ \\
\hline & $(0.250)$ & $(0.267)$ & $(0.273)$ \\
\hline \multirow{2}{*}{ ASSETS } & $-1.502^{\star * *}$ & $-1.742^{\star \star \star}$ & $-1.586^{* * *}$ \\
\hline & $(0.305)$ & $(0.372)$ & $(0.595)$ \\
\hline \multirow{2}{*}{$M K T V A L$} & $1.929^{\star * *}$ & $2.277^{\star \star \star}$ & $2.397^{\star * *}$ \\
\hline & $(0.316)$ & $(0.404)$ & $(0.625)$ \\
\hline \multirow{2}{*}{$A G E$} & -0.0774 & -0.232 & $-0.586^{\star}$ \\
\hline & $(0.239)$ & $(0.281)$ & $(0.348)$ \\
\hline \multirow{2}{*}{ Z-SCORE } & $-0.157^{\star * \star}$ & $-0.189^{* * *}$ & $-0.146^{\star *}$ \\
\hline & $(0.0370)$ & $(0.0417)$ & $(0.0692)$ \\
\hline \multirow{2}{*}{ Constant } & $-1.779^{\star *}$ & $-1.744^{*}$ & -2.276 \\
\hline & $(0.809)$ & $(0.957)$ & $(1.533)$ \\
\hline Observations & 2,010 & 1,461 & 598 \\
\hline Industry FE & YES & YES & YES \\
\hline $\begin{array}{l}\text { Year FE } \\
\text { Pseudo R-sq. } \\
\text { Wald chi2 }\end{array}$ & $\begin{array}{c}\text { YES } \\
0.0384 \\
75.67^{* * *}\end{array}$ & $\begin{array}{c}\text { YES } \\
0.0508 \\
63.81^{\star * *}\end{array}$ & $\begin{array}{c}\text { YES } \\
0.0727 \\
48.13^{* * *}\end{array}$ \\
\hline
\end{tabular}

Note: ${ }^{* *} \mathrm{p}<0.01,{ }^{* *} \mathrm{p}<0.05,{ }^{\star} \mathrm{p}<0.1$.

The section ends addressing the potential effects of the auditor-pair choice on the results. Accordingly, Eq. (4) is re-estimated after including 1BIG4FRANCE and 2BIG4FRANCE as the new variables of interest in substitution of FRANCE. Results, in Table 7, show that 1BIG4FRANCE and 2BIG4FRANCE present significant coefficients with positive sign in all three estimations. Accordingly, the auditor-pair choice does not seem to affect the results in Table 6. However, effects are stronger for those firms joint audited by a Big 4 and a non-Big 4 auditor. Hence, not only 1BIG4FRANCE has a larger coefficient than 2BIG4FRANCE in all three estimations, but also, it is more significant. As in Francis et al. (2009) and Deng et al. (2014), this suggests a more negative impact of joint audits on audit quality when one of the auditors is a non-Big4 firm. 


\section{Conclusions}

Even though nowadays joint audit is only mandatory in France, just a few years ago EU regulators seriously considered to impose it in the whole EU. Besides, in the UK, an intense debate is currently taking place about the convenience of imposing a mandatory joint audit rule. The results of this study do not indicate that French companies present significantly different levels of discretionary accruals than their European peers. The most interesting finding, however, is the higher likelihood of just beating earnings benchmarks for French firms (an indicator of poor audit quality), as no previous study has reported lower audit quality associated with joint audits. This result seems robust, as the statistical significance is strong and holds across numerous checks.

The different results observed for discretionary accruals and for earnings benchmarks reveal a main gap in the related literature, which so far measures audit quality almost exclusively by accruals. At a practical level, these findings are informative for the ongoing debate about the convenience of establishing a mandatory joint audit rule in Europe as well as in other countries.

The main limitation of this research is due to the design of the empirical analysis. The results indicate that French firms present similar or lower audit quality (depending on how audit quality is measured) than their European peers. Even though we control for the firms' specific characteristics, and conduct segmented analyses trying to offset the potential effects of a country's institutional setting on the results, it cannot be discarded that other factors not included in the analysis had affected the reported findings. Another limitation is the inability of generalizing the results to the whole universe of firms (and in particular, to medium and small-size firms), given the specific features of the sample of firms.

Finally, this study may be extended in some meaningful ways. First, given the different results reported for accruals and earnings benchmarks, it seems opportune to replicate this study with other indicators of audit quality. Additionally, an extension of this study based on another type of firms (i.e., medium-size firms) would complement the evidence provided here.

\section{Funding}

This work has received no funding.

\section{Author contributions}

Josep Garcia-Blandon conceived the study and was responsible for the design of the methodology. David Castillo-Merino and Josep M. Argilés-Bosch were responsible for data collection and interpretation, whereas Diego Ravenda conducted the statistical analysis.

\section{Disclosure statement}

The authors declare no competing financial, professional, or personal interests from other parties. 


\section{References}

Albersmann, B. T., \& Quick, R. (2020). The impact of audit quality indicators on the timeliness of goodwill impairments: Evidence from the German setting. Abacus, 56(1), 66-103. https://doi.org/10.1111/abac.12184

André, P., Broye, G., Pong, C., \& Schatt, A. (2016). Are joint audits associated with higher audit fees? European Accounting Review, 25(2), 245-274. https://doi.org/10.1080/09638180.2014.998016

Aobdia, D. (2019). Do practitioner assessments agree with academic proxies for audit quality? Evidence from PCAOB and internal inspections. Journal of Accounting and Economics, 67(1), 144-174. https://doi.org/10.1016/j.jacceco.2018.09.001

Ball, R., Kothari, S. P., \& Robin, A. (2000). The effect of international institutional factors on properties of accounting earnings. Journal of Accounting and Economics, 29(1), 1-51. https://doi.org/10.1016/S0165-4101(00)00012-4

Bédard, J. (2012). Discussion of "Audit Partner Specialization and Audit Fees: Some Evidence from Sweden". Contemporary Accounting Research, 29(1), 341-348. https://doi.org/10.1111/j.1911-3846.2011.01153.x

Bédard, J., Piot, C., \& Schatt, A. (2014). An evaluation of the French experience with joint auditing. https://doi.org/10.2139/ssrn.2165595

Carey, P. J., \& Simnett, R. (2006). Audit partner tenure and audit quality. The Accounting Review, 81(3), 653-676. https://doi.org/10.2308/accr.2006.81.3.653

Castillo-Merino, D., Garcia-Blandon, J., \& Martinez-Blasco, M. (2020). Auditor independence, current and future NAS fees and audit quality: Were European regulators right? European Accounting Review, 29(2), 233-262. https://doi.org/10.1080/09638180.2019.1577151

Competition and Markets Authority. (2019). Statutory audit services market study (Final report 18 April 2019). https://assets.publishing.service.gov.uk/media/5d03667d40f0b609ad3158c3/audit_final_report_02.pdf

DeAngelo, L. E. (1981). Auditor size and audit quality. Journal of Accounting and Economics, 3(3), 183-199. https://doi.org/10.1016/0165-4101(81)90002-1

DeFond, M., \& Park, C. W. (2001). The reversal of abnormal accruals and the market valuation of earnings surprises. The Accounting Review, 76(3), 375-404. https://doi.org/10.2308/accr.2001.76.3.375

DeFond, M., \& Zhang, J. (2014). A review of archival auditing research. Journal of Accounting and Economics, 58(2-3), 275-326. https://doi.org/10.1016/j.jacceco.2014.09.002

Deng, M., Lu, T., Simunic, D. A., \& Ye, M. (2014). Do joint audits improve or impair audit quality? Journal of Accounting Research, 52(5), 1029-1060. https://doi.org/10.1111/1475-679X.12060

European Commission. (2010). Green paper: Audit policy: Lessons from the crisis (COM(2010) 561 final). Publications Office of the European Union. https://eur-lex.europa.eu/legal-content/EN/TXT/ $\mathrm{PDF} /$ ?uri=CELEX:52010DC0561\&from $=\mathrm{EN}$

European Parliament. (2014). Regulation (EU) No 537/2014 of the European Parliament and of the Council of 16 April 2014 on specific requirements regarding statutory audit of public-interest entities and repealing Commission decision 2005/909/EC. Publications Office of the European Union. https://eur-lex.europa.eu/legal-content/EN/TXT/?uri=CELEX\%3A32014R0537

Financial Times. (2020, February 19). Watchdog threatens audit firms with extra reforms. https://www.ft.com/content/10a77c5a-5260-11ea-8841-482eed0038b1

Francis, J. R., \& Wang, D. (2008). The joint effect of investor protection and Big 4 audits on earnings quality around the world. Contemporary Accounting Research, 25(1), 157-191.

https://doi.org/10.1506/car.25.1.6 
Francis, J. R., Richard, C., \& Vanstraelen, A. (2009). Assessing France's joint audit requirement: Are two heads better than one? Auditing: A Journal of Practice \& Theory, 28(2), 35-63. https://doi.org/10.2308/aud.2009.28.2.35

Garcia-Blandon, J., Argilés-Bosch, J. M., \& Ravenda, D. (2020). Audit firm tenure and audit quality: A cross-European study. Journal of International Financial Management \& Accounting, 31(1), 35-64. https://doi.org/10.1111/jifm.12098

Holm, C., \& Thinggaard, F. (2018). From joint to single audits-audit quality differences and auditor pairings. Accounting and Business Research, 48(3), 321-344. https://doi.org/10.1080/00014788.2017.1381910

Hoos, F., Pruijssers, J. L., \& Lander, M. W. (2019). Who's watching? Accountability in different audit regimes and the effects on auditors' professional skepticism. Journal of Business Ethics, 156(2), 563-575. https://doi.org/10.1007/s10551-017-3603-6

Institute of Chartered Accountants in England and Wales. (2019). Shared and joint audits: Are two auditors better than one? ICAEW, London. https://www.icaew.com/-/media/corporate/files/technical/ audit-and-assurance/the-future-of-audit/shared-and-joint-audits.ashx

International Federation of Accountants. (2020). Joint audit: The bottom line - No clear evidence. IFAC, New York. https://www.ifac.org/system/files/publications/files/IFAC-Joint-Audit-The-Bottom-Line. pdf

Kermiche, L., \& Piot, C. (2018). The audit market dynamics in a mandatory joint audit setting: The French experience. Journal of Accounting, Auditing \& Finance, 33(4), 463-484. https://doi.org/10.1177/0148558X16680716

La Porta, R., Lopez-de-Silanes, F., Shleifer, A., \& Vishny, R. (1998). Law and Finance. Journal of Political Economy, 106(6), 1113-1155. https://doi.org/10.1086/250042

Lesage, C., Ratzinger-Sakel, N. V. S., \& Kettunen, J. (2017). Consequences of the abandonment of mandatory joint audit: An empirical study of audit costs and audit quality effects. European Accounting Review, 26(2), 311-339. https://doi.org/10.1080/09638180.2016.1152558

Lobo, G. J., Paugam, L., Zhang, D., \& Casta, J. F. (2017). The effect of joint auditor pair composition on audit quality: Evidence from impairment tests. Contemporary Accounting Research, 34(1), 118-153. https://doi.org/10.1111/1911-3846.12244

Menon, K., \& Williams, D. D. (2004). Former audit partners and abnormal accruals. The Accounting Review, 79(4), 1095-1118. https://doi.org/10.2308/accr.2004.79.4.1095

Nurunnabi, M., Donker, H., \& Jermakowicz, E. (2020). Joint audits and mutual ties of audit firm networks. Business Horizons, 63(4), 435-449. https://doi.org/10.1016/j.bushor.2020.03.013

Quick, R., \& Schmidt, F. (2018). Do audit firm rotation, auditor retention, and joint audits matter? An experimental investigation of bank directors' and institutional investors' perceptions. Journal of Accounting Literature, 41, 1-21. https://doi.org/10.1016/j.acclit.2018.01.003

Ratzinger-Sakel, N. V. S., Audousset-Coulier, S., Kettunen, J., \& Lesage, C. (2013). Joint audit: Issues and challenges for researchers and policy makers. Accounting in Europe, 10(2), 175-199. https://doi.org/10.1080/17449480.2013.834725

Siddiqui, J. (2019). Are four eyes better than two? An examination of recent empirical evidence on the impact of joint audits. University of Manchester. https://assets.publishing.service.gov.uk/ media/5c63fcd840f0b676d487d06b/dr_javed_siddiqui_response_to_update_paper.pdf 